\title{
Pengembangan Modul IPA Berbasis Creative Problem Solving (CPS) untuk Meningkatkan Kemampuan Berpikir Kreatif Siswa
}

\section{Development of Creative Problem Solving (CPS)-based Integrated Natural Science Module to Improve Students' Creative Thinking}

\author{
Sondra Swestyani ${ }^{1 *}$, Mohammad Masyuri ${ }^{2}$, Baskoro Adi Prayitno ${ }^{3}$ \\ ${ }^{1}$ Magister Pendidikan Sains Fakultas Keguruan dan Ilmu Pendidikan Universitas Sebelas Maret, Surakarta, 57126, Indonesia \\ ${ }^{2}$ Pendidikan Fisika Fakultas Keguruan dan Ilmu Pendidikan Universitas Sebelas Maret, Surakarta, 57126, Indonesia \\ ${ }^{3}$ Pendidikan Biologi Fakultas Keguruan dan Ilmu Pendidikan Universitas Sebelas Maret, Surakarta, 57126, Indonesia \\ *Corresponding authors: swestyani@yahoo.co.id
}

Manuscript received: ......... Revision accepted:

\begin{abstract}
Penelitian ini dilatarbelakangi oleh kebutuhan sumber daya manusia yang mampu berpikir kreatif untuk memecahkan masalah. Salah satu cara untuk mengatasinya adalah mengoptimalkan peningkatan kemampuan berpikir kreatif pada siswa. Penelitian ini bertujuan untuk mengetahui kelayakan dan efektifitas modul IPA berbasis Creatif Problem Solving (CPS) untuk meningkatkan kemampuan berpikir kreatif siswa. Penelitian ini merupakan jenis penelitian Research and Development. Pengembangan modul menggunakan model four-d mengacu pada model Borg \& Gall, meliputi tahap define, design, development,dan disseminate. Modul dikembangkan menggunakan model pembelajaran Creatif Problem Solving (CPS), meliputi tahap objective finding, fact finding, problem finding, idea finding, solution finding, dan acceptance finding. Teknik Pengumpulan data menggunakan angket dan soal tes open-ended. Pengujian menggunakan metode eksperimen pretest postest control group design yang melibatkan 30 siswa kelas VII untuk setiap grup. Teknik analisis data menggunakan analisis deskriptif untuk menganalisis kelayakan modul dan t-test untuk menganalisis kemampuan berpikir kreatif. Hasil penelitian menunjukkan bahwa kelayakan modul hasil pengembangan adalah sangat baik berdasarkan penilaian ahli, praktisi, dan teman sejawat. Berdasarkan hasil uji-t terdapat perbedaan yang signifikan antara hasil pretest dan posttest pada kemampuan berpikir kreatif yaitu 0,000. Hasil n-gain kemampuan berpikir kreatif pada kelas eksperimen adalah 0,368 (sedang), n-gain kemampuan berpikir kreatif pada kelas kontrol adalah 0,150 (rendah). Hal ini menunjukkan bahwa modul IPA berbasis Creatif Problem Solving (CPS) memiliki efektifitas tinggi dan mampu meningkatkan kemampuan berpikir kreatif siswa serta layak digunakan dalam pembelajaran.
\end{abstract}

Keywords: modul, creative problem solving, kemampuan berpikir kreatif

\section{PENDAHULUAN}

Perkembangan ilmu suatu bangsa, menunjukan seberapa maju bangsa tersebut. Semakin dalam pengetahuan yang dimiliki seseorang, maka semakin besar kemampuanya untuk mengeksplorasi potensi kreatifnya. Hong dan Jhon (2012: 48) mengatakan bahwa berpikir kreatif dikembangkan berdasarkan pengetahuan, sekolah adalah salah satu tempat dimana siswa memperoleh dan membangun pengetahuan tersebut. Semua negara baik negara miskin, negara berkembang bahkan negara maju membutuhkan kemampuan untuk mengembangkan berpikir kreatif. Rendahnya kemampuan berpikir kreatif akan berdampak pada kualitas sumber daya manusia.

Kemampuan berpikir kreatif akan membekali siswa dalam persaingan dunia kerja yang menuntut siswa lebih kreatif dan cakap. Sumber daya manusia yang kreatif tidak mungkin tumbuh secara alami melainkan harus melalui suatu proses yang dilakukan secara sistematis, konsisten, profesional dan berkesinambungan, salah satu diantaranya melalui kegiatan pembelajaran di sekolah.

Pengembangan kemampuan berpikir kreatif dan keterampilan generik menjadi esensial bagi setiap orang, sebagai bekal agar mampu membuat pertimbangan atau mengevaluasi pernyataan, melakukan analisis sebelum membuat keputusan, dan mampu membuat argumen untuk mempertahankan pendapat. Selain itu, dalam semua disiplin ilmu dan dunia kerja mensyaratkan siswa untuk mampu: (1) memiliki kepercayaan diri; (2) memiliki motivasi berprestasi; (3) menguasai keterampilan berpikir, seperti mengajukan pertanyaan, mengambil keputusan, berpikir analitis, kritis, dan berpikir kreatif; (4) menguasai keterampilan interpersonal; dan (5) menguasai keterampilan-keterampilan dasar (Career Center Maine Department of Labor USA, 2001).

Kemampuan berpikir kreatif merupakan keterampilan kognitif untuk memunculkan dan mengembangkan gagasan baru, ide baru sebagai pengembangan dari ide yang telah lahir sebelumnya dan keterampilan untuk memecahkan masalah dari berbagai sudut pandang (Liliawati dan Puspita, 2010: 425).

Pendidikan nasional yang berfungsi untuk mengembangkan kemampuan dan membentuk watak serta memiliki tujuan untuk mengembangkan potensi peserta didik agar menjadi manusia yang berilmu, cakap, dan kreatif. Ilmu Pengetahuan Alam (IPA) menyediakan berbagai pengalaman belajar untuk memahami metode dan 
proses sains (Irawati, 2012). Pengalaman belajar yang diterima dengan baik diharapkan mampu mengembangkan kemampuan berpikir kreatif sains dalam diri siswa.

Paradigma utama dunia pendidikan di Indonesia pada kenyataannya pembelajaran yang ada hanya memperkuat kekuatan otak kiri (intelektualitas). Sementara pengembangan otak kanan (berpikir kreatif) masih kurang. Dampak dari paradigma yang terjadi saat ini adalah minimnya kreatifitas yang dimiliki oleh orang-orang berpendidikan (Indra, 2006: 129). Pernyataan ini diperkuat berdasarkan peringkat kreativitas Indonesia dalam Creativity and Prosperity: Global Creativity Index tahun 2010 yang dipublikasikan oleh Martin Prosperity Institute (MPI) bahwa Indonesia berada pada peringkat 81 dari 82 negara (MPI, 2011: 41)

Akar penyebab bervariasinya kemampuan berpikir kreatif siswa bisa bersumber dari guru, siswa, dan lingkungan. Menurut Wahyudin dalam Mina (2006) di antara penyebab rendahnya pencapaian berpikir kreatif adalah belum tersedianya bahan ajar yang mendukung aktivitas kemampuan berpikir kreatif. Guru selama ini belum menggunakan bahan ajar lain selain buku dan LKS, sehingga aktivitas pembelajaran belum mendukung pemecahan masalah.

Salah satu komponen yang menunjang upaya peningkatan kemampuan berpikir kreatif siswa melalui pembelajaran yaitu penggunaan bahan ajar yang disesuaikan dengan karakteristik dan kebutuhan siswa. Modul yang mengakomodasi kemampuan berpikir kreatif yaitu modul yang didukung dengan penggunaan model pembelajaran yang tepat sehingga mampu membuat peserta didik belajar dengan efektif. Pehkonen (1997) berpendapat bahwa cara untuk meningkatkan berpikir kreatif dan keterampilan generik yaitu melalui pendekatan pemecahan masalah.

Model pembelajaran yang digunakan sebagai pendukung modul adalah model Creative Problem Solving (CPS). Menurut Karen (2004: 1), model Creative Problem Solving (CPS) adalah suatu model pembelajaran yang berpusat pada keterampilan pemecahan masalah, yang diikuti dengan penguatan kreatifitas. Langkah pembelajaran dari model Creative Problem Solving menurut Osborn (1953) yang telah diperbarui yaitu disebut 6 diamond models menurut vidal (2006) terdiri dari mess finding, fact finding, problem finding, idea finding, solution finding, dan acceptance finding.

Modul berbasis Creative Problem Solving (CPS) bertujuan untuk meningkatkan kemampuan berpikir kreatif siswa. Model Creative Problem Solving (CPS) menekankan pada ketrampilan memecahkan masalah untuk memilih dan mengembangkan tanggapannya. Tidak hanya dengan cara menghafal tanpa dipikir, ketrampilan memecahkan masalah memperluas proses berpikir.Kemampuan berpikir kreatif yang ditingkatkan terdiri dari lima yaitu, fluency, flexibility, originality, evaluation, dan elaboration.

Modul berbasis Creative Problem Solving (CPS) memiliki kelemahan membutuhkan kemampuan memahami, menghubungkan, mencari variasi ide, menemukan ide baru dengan tingkat pemahaman dan kecerdasan siswa yang berbeda-beda, sehingga penggunaan model $C P S$ perlu dipadu dengan sebuah metode yang mampu melengkapi kekurangan model $C P S$ yaitu mind mapping. Mind mapping adalah alat visual dan verbal yang digunakan untuk memetakan situasi yang kompleks dan mengembangkan ide selama proses creative problem solving (Vidal, 2004). Mind maping mendorong siswa untuk menggeneralisasi ide baru melalui brainstorming, memudahkan membuat hubungan baru sehingga menambah ide, gagasan untuk topik yang bervariasi (Al-Jarf, 2009). Metode mind mapping digunakan untuk mengefektifkan Model Pembelajaran Creative Problem Solving pada saat elaboration di tahap pembelajaran solution finding.

\section{METODE PENELITIAN}

Penelitian ini merupakan penelitian pengembangan (research and development) yang bertujuan untuk mengembangkan modul pembelajaran IPA SMP berbasis Creative Problem Solving pada materi pemanasan global untuk meningkatkan kemampuan berpikir kreatif. Model yang digunakan sebagai dasar untuk mengembangkan modul pembelajaran IPA ini merupakan hasil adaptasi model 4D (four-D model) yang dikemukakan oleh Thiagarajan (1974:5). Model 4D sering dikenal dengan model 4P yaitu pendefinisian, perancangan, pengembangan, dan penyebaran.

Penelitian ini dilaksanakan di SMP Negeri 1 Karangsambung, Kebumen. Desain penelitian menggunakan metode pretest posttest control group design. Subyek penelitian untuk uji coba skala luas adalah siswa kelas VII A sejumlah 30 siswa (kelas eksperimen) dan kelas VII D sejumlah 30 siswa (kelas kontrol). Uji coba skala terbatas dilakukan di kelas VII C sejumlah 10 siswa. Teknik pengambilan sampel menggunakan simple random sampling.

Instrumen pengumpulan data pada penelitian ini adalah dengan metode angket dan tes. Pengisian angket untuk memperoleh data respon siswa dan guru mengenai keefektifan modul yang dikembangkan, sedangkan tes digunakan untuk mengetahui hasil kemampuan berpikir kreatif siswa. Tes yang digunakan dalam penelitian ini adalah tes awal (pretest) dan tes akhir (posttest) yang berupa tes open-ended.

Data yang diperoleh dianalisis secara deskriptif berdasarkan hasil validasi ahli, praktisi pendidikan dan teman sejawat serta hasil angket respon siswa dan guru. Kedua, hasil tes kemampuan berpikir kreatif yang dianalisis dengan menghitung jumlah jawaban siswa yang relevan. Kemudian hasil tes tersebut diuji dengan uji Independent sample t-test untuk mengetahui ada tidaknya perbedaan sebelum dan sesudah diberikan perlakuan. Hasil tes kemampuan berpikir kreatif siswa juga dianalisis dengan $N$-Gain Score untuk mengetahui peningkatan kemampuan berpikir kreatif siswa selama mengikuti pembelajaran. 


\section{HASIL DAN PEMBAHASAN}

Tahap pertama dalam penelitian ini yaitu tahap pendefinisian. Tahap pendefinisian berupa studi literatur, pemilihan sekolah, pemilihan materi, dan observasi sekolah. Hasil studi literatur menunjukkan bahwa semua negara baik negara miskin, negara berkembang bahkan negara maju membutuhkan kemampuan untuk mengembangkan berpikir kreatif. Rendahnya kemampuan berpikir kreatif akan berdampak pada kualitas sumber daya manusia. Kenyataan yang terjadi di Indonesia adalah masih minimnya sumber daya yang kreatif dan memiliki keterampilan kerja dasar yang baik. Pernyataan ini diperkuat berdasarkan peringkat kreativitas Indonesia dalam Creativity and Prosperity: Global Creativity Index tahun 2010 yang dipublikasikan oleh Martin Prosperity Institute (MPI) bahwa Indonesia berada pada peringkat 81 dari 82 negara (MPI, 2011: 41).

Sekolah yang dipilih sebagai lokasi penelitian dan pengembangan ini adalah SMP Negeri 1 Karangsambung. Alasan pemilihan sekolah ini yaitu sekolah ini merupakan sekolah Adiwiyata yang menekankan siswanya untuk senantiasa menjaga lingkungan sekitar. Hal ini mendukung untuk penelitian dengan materi pemanasan global karena siswa diajak untuk melatih keterampilan generik sains dan berpikir kreatif tentang masalah yang ada di lingkungan, mencari solusi, dan menerapkannya dalam kehidupan sehari-hari.

Materi yang dipilih dalam penelitian dan pengembangan ini adalah materi pemanasan global. Pemanasan global dipilih karena materi ini relevan dengan keadaan lingkungan di sekitar sekolah. Kondisi lingkungan di sekitar sekolah yang banyak dipengaruhi oleh kegiatan manusia seperti penggunaan bahan bakar fosil pada kendaraan terutama truk pengangkut pasir yang banyak melintasi jalan di sekitar sekolah, limbah industri rumah tangga, penambangan pasir liar, alih fungsi hutan sehingga meningkatkan pemanasan global . Di akhir pembelajaran diharapkan siswa mampu menemukan solusi dan menerapkannya di lingkungan sekitar.

Hasil observasi sekolah bahwa pembelajaran masih berpusat pada guru. Bahan ajar belum disesuaikan dengan karakteristik dan kebutuhan peserta didik karena diambil dari buku ajar saja. Bahan ajar yang digunakan belum memiliki komponen yang memicu aktivitas peserta didik untuk menganalisis fakta yang ada, memunculkan rasa ingin tahu, keterampilan melakukan pengamatan dan percobaan, serta mencari alternatif pemecahan masalah dari berbagai sudut pandang. Kesesuaian sistem pendukung (sumber belajar, LKS, peralatan laboatorium, dan media pembelajaran) dengan proses pembelajaran yaitu 50\%$75 \%$. Sumber belajar yang digunakan didominasi oleh buku pelajaran yang diterbitkan percetakan, pemanfaatan lingkungan sekitar dan internet masih terbatas.

Tahap kedua yaitu tahap perancangan dengan menyusun modul draft I yang terdiri dari desain awal modul yang terdiri dari mosul siswa dan modul guru. Desain awal modul siswa berisi cover, petunjuk pembuatan mind mapping, kata pengantar, daftar isi, daftar gambar, daftar tabel, pendahuluan, uraian materi, penutup, uji kompetensi, kunci jawaban, glosarium dan daftar pustaka. Desain awal modul guru berisi cover, petunjuk pembuatan mind mapping, kata pengantar, daftar isi, daftar gambar, daftar tabel, pendahuluan, kegiatan pembelajaran 1, kegiatan pembelajaran 2, kesimpulan, uji kompetensi, kunci jawaban, glosarium dan daftar pustaka.

Tahap ketiga yaitu tahap pengembangan. Produk awal berupa modul draft II yang sudah dikembangkan, selanjutnya dilakukan validasi oleh ahli materi, ahli pembelajaran, ahli media, dan ahli bahasa. Rekapitulasi hasil validasi disajikan pada Tabel 1 berikut ini:

Tabel 1. Hasil Penilaian Modul oleh Ahli, Praktisi Pendidikan dan Teman Sejawat

\begin{tabular}{|c|c|c|c|}
\hline Validasi & $\begin{array}{c}\text { Rata- } \\
\text { rata }\end{array}$ & $\begin{array}{c}\text { Persentase } \\
(\%)\end{array}$ & Kategori \\
\hline Ahli Materi & 3.87 & 96.75 & $\begin{array}{l}\text { Sangat } \\
\text { baik }\end{array}$ \\
\hline $\begin{array}{c}\text { Ahli } \\
\text { Pembelajaran }\end{array}$ & 3.81 & 95.25 & $\begin{array}{l}\text { Sangat } \\
\text { baik }\end{array}$ \\
\hline Ahli Media & 3.56 & 89.00 & $\begin{array}{l}\text { Sangat } \\
\text { baik }\end{array}$ \\
\hline Ahli Bahasa & 4.00 & 100 & $\begin{array}{l}\text { Sangat } \\
\text { baik }\end{array}$ \\
\hline
\end{tabular}

Berdasarkan hasil validasi ahli materi, ahli pembelajaran, ahli media, dan ahli bahasa pada tabel 1 secara umum kelayakan modul yang dikembangkan berkategori "Sangat baik".

Uji coba terbatas melibatkan 10 orang siswa dari kelas VII C yang terdiri dari 5 orang siswa dengan kemampuan tinggi dan 5 orang siswa dengan kemampuan rendah. Pengambilan siswa pada uji coba terbatas dengan tingkat penguasaan kognitif yang berbeda dimaksudkan agar hasil penelitian yang diperoleh dapat mewakili keseluruhan siswa yang ada di lapangan yang memiliki kemampuan beragam. Teknik pemilihan sampel ini disebut teknik purpossive sampling. Teknik purpossive sampling adalah teknik penentuan sampel dengan pertimbangan tertentu (Sugiyono, 2012). Hasil uji coba terbatas modul dapat dilihat pada tabel 2 .

Tabel 2. Rekapitulasi Hasil Uji Coba Terbatas

\begin{tabular}{|c|c|c|c|c|c|c|}
\hline \multirow[t]{2}{*}{ Nama } & \multicolumn{5}{|c|}{$\begin{array}{c}\text { Indikator Kemampuan Berpikir } \\
\text { Kreatif } \\
\end{array}$} & \multirow[t]{2}{*}{$\begin{array}{l}\text { Rata } \\
\text {-rata }\end{array}$} \\
\hline & 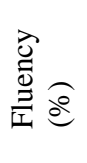 &  & 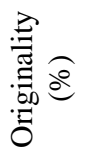 &  &  & \\
\hline Siswa 1 & 70 & 70 & 70 & 74 & 78 & 72,4 \\
\hline Siswa 2 & 70 & 70 & 70 & 74 & 78 & 72,4 \\
\hline Siswa 3 & 92 & 92 & 91 & 82 & 75 & 86,4 \\
\hline Siswa 4 & 73 & 73 & 73 & 74 & 76 & 73,8 \\
\hline Siswa 5 & 96 & 96 & 97 & 96 & 100 & 97 \\
\hline Siswa 6 & 92 & 92 & 84 & 75 & 75 & 83,6 \\
\hline Siswa 7 & 74 & 74 & 73 & 70 & 72 & 72,6 \\
\hline
\end{tabular}




\begin{tabular}{lrrrrrr}
\hline Siswa 8 & 88 & 88 & 91 & 86 & 83 & 87,2 \\
Siswa 9 & 100 & 100 & 97 & 96 & 92 & 97 \\
Siswa 10 & 70 & 70 & 73 & 74 & 78 & 73 \\
& \multicolumn{7}{c}{ Rata-rata } & & & $\mathbf{8 1 . 5 4}$ \\
\hline
\end{tabular}

Berdasarkan Tabel 2 diketahui bahwa rata-rata hasil uji coba terbatas secara keseluruhan adalah 81.54 dengan kriteria baik. Dengan demikian dapat disimpulkan bahwa modul IPA berbasis CPS efektif digunakan dalam pembelajaran. Efektifitas modul menunjukkan tingkat keterbacaan, penguasaan dan pemahaman siswa terhadap modul yang tinggi (Daryanto, 2013).

Uji coba skala luas menggunakan true experimental design jenis control group pretest posttest design, artinya desain u68ji menggunakan dua kelas yaitu kelas kontrol (menggunakan buku paket yang biasa digunakan di sekolah) dan kelas perlakuan (menggunakan modul berbasis CPS). Kedua kelas sama-sama diberikan pretest terlebih dahulu sebelum menerima perlakuan, kemudian dilanjutkan dengan memberikan posttest pada kedua kelas tersebut (Sugiyono, 2013). Pada tahap implementasi ini siswa kelas VII D menjadi kelas kontrol dan siswa kelas VII A menjadi kelas perlakuan.

Analisis data yang digunakan untuk mengetahui perbedaan skor kemampuan berpikir kreatif pada kelas kontrol dan kelas eksperimen menggunakan uji prasyarat yaitu uji normalitas, uji homogenitas dan uji-t. Ringkasan uji normalitas, homogenitas dan uji-t skor kelas kontrol dan kelas eksperimen dapat dilihat pada Tabel 3.

Berdasarkan hasil uji presyarat, maka uji hipotesis menggunakan uji statistik parametrik yaitu uji-t Independent Sample Test bagian Sig. (2-tailed). Pada hasil Independent Sample Test bagian Sig. (2-tailed) sebesar 0.000 memenuhi taraf signifikansi $\alpha=0.05$ (Sig < 0.05) maka hasil analisis skor kemampuan berpikir kreatif kelas kontrol dan kelas eksperimen didapatkan kesimpulan bahwa ada perbedaan secara signifikan antara skor pada kelas kontrol dan kelas eksperimen, sehingga terdapat perbedaan yang signifikan antara kemampuan berpikir kretaif siswa antara kelas yang menggunakan modul berbasis CPS dengan kelas yang tidak menggunakan modul berbasis CPS.

Tabel 3. Rekapitulasi Hasil Analisis Skor Kemampuan Berpikir Kreatif

\begin{tabular}{|c|c|c|}
\hline & \multicolumn{2}{|c|}{ Hasil } \\
\hline \multirow{4}{*}{$\begin{array}{c}\text { Normalitas } \\
\text { (Kolmogorov } \\
\text { Smirnov) }\end{array}$} & $\begin{array}{c}\text { Skor Pretest } \\
\text { Kelas Kontrol }\end{array}$ & $0.132>0.05$ \\
\hline & Kelas Eksperimen & $0.138>0.05$ \\
\hline & $\begin{array}{l}\text { Skor Posttest } \\
\text { Kelas kontrol }\end{array}$ & $0.249>0.05$ \\
\hline & Kelas eksperimen & $0.135>0.05$ \\
\hline $\begin{array}{l}\text { Homogenitas } \\
\text { (Levene }\end{array}$ & Skor Pretest & $1.116>0.05$ \\
\hline Statistic) & Skor Posttest & $0.850>0.05$ \\
\hline
\end{tabular}

\begin{tabular}{ccc}
\hline Uji-t & $\begin{array}{c}\text { Postest kelas } \\
\text { eksperimen dan } \\
\text { kelas kontrol }\end{array}$ & $0.000<0.05$ \\
N-Gain Score & $\begin{array}{c}\text { Kelas Eksperimen } \\
\text { Kelas Kontrol }\end{array}$ & 0,368 \\
& & 0,150 \\
\hline
\end{tabular}

Analisis untuk mengetahui keefektifan modul pembelajaran dengan menggunakan gain score untuk posttest kelas kontrol dan kelas eksperimen.. Berdasarkan perhitungan $\mathrm{N}$-gain score kelas kontrol meperoleh nilai sebesar 0.150 yang menunjukkan kategori rendah, sedangkan untuk kelas eksperimen memperoleh nilai sebesar 0.368 yang menunjukkan kategori sedang. Hal ini membuktikan bahwa penggunaan modul IPA berbasis CPS dapat meningkatkan kemampuan berpikir kreatif siswa.

Modul yang mengakomodasi kemampuan berpikir kreatif yaitu modul yang didukung dengan penggunaan model pembelajaran yang tepat sehingga mampu membuat peserta didik belajar dengan efektif. Munandar (2003:13) menjelaskan bahwa perkembangan optimal dari kemampuan berpikir kreatif berhubungan erat dengan cara mengajar. Pehkonen (1997:66) berpendapat bahwa cara untuk meningkatkan berpikir kreatif yaitu melalui pendekatan pemecahan masalah. Weisberg dalam Haylock (1997:72) menjelaskan bahwa terdapat hubungan antara pemecahan masalah dengan kemampuan berpikir kreatif.

Menurut Karen (2004: 1), model Creative Problem Solving (CPS) adalah suatu model pembelajaran yang berpusat pada ketrampilan pemecahan masalah, yang diikuti dengan penguatan kreatifitas. Ketika dihadapkan dengan situasi pertanyaan, siswa dapat melakukan ketrampilan memecahkan masalah untuk memilih dan mengembangkan tanggapannya. Tidak hanya dengan cara menghafal tanpa dipikir, ketrampilan memecahkan masalah memperluas proses berpikir. Suatu soal yang dianggap sebagai "masalah" adalah soal yang memerlukan keaslian berpikir tanpa adanya contoh penyelesaian sebelumnya. Masalah berbeda dengan soal latihan. Pada masalah ini, siswa tidak tahu bagaimana cara menyelesaikannya, tetapi siswa tertarik dan tertantang untuk menyelesaikannya. Siswa menggunakan segenap pemikiran, memilih strategi pemecahannya, dan memproses sampai menemukan penyelesaian dari suatu masalah (Trianto, 2007 : 30). Model pembelajaran CPS merupakan variasi pembelajaran berbasis masalah melalui teknik sistematik dalam mengorganisasikan gagasan kreatif untuk menyelesaikan suatu permasalahan.

Model Creative Problem Solving memiliki kelemahan utama yaitu membutuhkan kemampuan memahami, menghubungkan, mencari variasi ide, menemukan ide baru dengan tingkat pemahaman dan kecerdasan siswa yang berbeda-beda, sehingga diperlukan pada tahap elaborasi di sintak solution finding yang pada umumnya disampaikan secara verbal dimodifikasi dengan penggunaan mind mapping. Mind mapping membantu siswa memetakan permasalahan sehingga waktu yang diperlukan lebih efektif dan efisien. Mind mapping adalah alat visual dan verbal yang digunakan untuk memetakan situasi yang kompleks 
dan mengembangkan ide selama proses creative problem solving (Vidal, 2004).

Mind mapping dapat meningkatkan daya hafal dan pemahaman konsep siswa serta meningkatkan daya berpikir kreatif siswa melalui kebebasan berimajinasi dengan memproyeksikan suatu topik permasalahan dengan warna dan gambar yang menarik (Sugiarto, 2004), sehingga pembelajaran yang dilakukan menjadi pembelajaran yang bermakna (Hudojo, 2003).

Mind mapping melatih otak siswa untuk mengembangkan topik permasalahan secara kreatif yang dituangkan dalam gambar berwarna, cabang-cabang yang melengkung membuat otak tidak bosan, dan kebebasan berimajinasi sehingga apa yang sudah dipelajari mampu menjadi memori jangka panjang bagi siswa yang nantinya berpengaruh pada hasil belajar kognitif siswa yang lebih baik (Nugroho,2011).

Setelah kegiatan pembelajaran dengan menggunakan modul selesai,, siswa diberi lembar angket yang berisi respon, masukan dan penilaian terhadap modul. Data hasil tanggapan siswa digunakan untuk memperoleh pendapat siswa tentang kelayakan modul materi pemanasan global yang berbasis CPS untuk diterapkan pada proses pembelajaran. Hasil analisis angket tanggapan siswa terhadap modul yang telah dikembangkan ditampilkan pada Tabel 4. Angket diberikan kepada 30 siswa di kelas VII A (kelas eksperimen) yang mencangkup terdiri dari 12 item. Respon siswa di kelas VII A menjawab dengan ratarata 3,27 termasuk kategori sangat baik.

Tabel 4. Rekapitulasi Hasil Analisis Angket Siswa

\begin{tabular}{cccl}
\hline $\begin{array}{c}\text { Pernyataa } \\
\text { n }\end{array}$ & $\begin{array}{c}\text { Skor } \\
\text { diperoleh }\end{array}$ & $\begin{array}{c}\text { Rata- } \\
\text { rata }\end{array}$ & Kriteria \\
\hline 1 & 99 & 3,3 & Sangat Baik \\
2 & 102 & 3,4 & Sangat baik \\
3 & 100 & 3,33 & Sangat baik \\
4 & 100 & 3,33 & Sangat baik \\
5 & 96 & 3,2 & Sangat baik \\
6 & 97 & 3,23 & Sangat baik \\
7 & 86 & 2,86 & Sangat baik \\
8 & 92 & 3,06 & Sangat baik \\
9 & 98 & 3,26 & Sangat baik \\
10 & 99 & 3,3 & Sangat Baik \\
11 & 102 & 3,4 & Sangat baik \\
12 & 108 & 3,6 & Sangat baik \\
Rata-Rata & 98,25 & 3,27 & Sangat Baik \\
\hline
\end{tabular}

Tahapan keempat adalah disseminate, pada tahap ini dilakukan penyebaran modul di 2 Sekolah Menengah Pertama yang ada di Kecamatan Karangsambung, Kabupaten Kebumen. Penyebaran dilakukan pada guru IPA dan selanjutnya diberikan angket yang berisi respon guru terhadap modul yang dikembangkan. Hasil tanggapan guru digunakan untuk memperoleh pendapat guru tentang kelayakan modul IPA berbasis CPS yang telah dikembangkan dengan menggunakan angket tanggapan guru. Data secara rinci disajikan pada Tabel 5.
Tabel 5. Rekapitulasi Hasil Analisis Angket Guru

\begin{tabular}{cccc}
\hline Pernyataan & $\begin{array}{c}\text { Skor } \\
\text { diperoleh }\end{array}$ & $\begin{array}{c}\text { Rata- } \\
\text { rata }\end{array}$ & Kriteria \\
\hline 1 & 17 & 3,4 & Sangat Baik \\
2 & 18 & 3,6 & Sangat baik \\
3 & 18 & 3,6 & Sangat baik \\
4 & 17 & 3,4 & Sangat baik \\
5 & 19 & 3,8 & Sangat baik \\
6 & 16 & 3,2 & Sangat baik \\
7 & 18 & 3,6 & Sangat baik \\
8 & 18 & 3,6 & Sangat baik \\
9 & 17 & 3,4 & Sangat baik \\
10 & 18 & 3,6 & Sangat Baik \\
11 & 18 & 3,6 & Sangat baik \\
12 & 17 & 3,4 & Sangat baik \\
13 & 17 & 3,4 & Sangat baik \\
14 & 16 & 3,2 & Sangat baik \\
15 & 18 & 3,6 & Sangat baik \\
Rata-Rata & 262 & 3,49 & Sangat Baik \\
\hline
\end{tabular}

Berdasarkan hasil analisis angket respon guru, hasil penilaian dan tanggapan guru-guru IPA rata-rata sebesar 3.49 , rentang nilai tersebut termasuk dalam kategori sangat baik dan layak digunakan.

\section{KESIMPULAN}

Berdasarkan hasil penelitian dan pembahasan dapat disimpulkan bahwa kualitas modul berdasarkan hasil validasi modul IPA berbasis Creatif Problem Solving (CPS) pada materi pemanasan global yang dikembangkan termasuk dalam katagori sangat baik, sedangkan untuk respon siswa dan guru yang menyatakan modul sangat baik atau layak untuk digunakan. Modul IPA berbasis Creatif Problem Solving (CPS) pada materi pemanasan global efektif dalam meningkatkan kemampuan berpikir kreatif siswa berdasarkan hasil $\mathrm{N}$-gain score sebesar 0,368 yang menunjukkan kategori tinggi.

\section{UCAPAN TERIMAKSIH}

Terimakasih untuk kepala sekolah, guru IPA SMP Negeri 1 Karangsambung, siswa kelas VII A, VII D, VII C, yang telah membantu dalam penelitian ini.

\section{DAFTAR PUSTAKA}

Al-Jarf, R. (2009), 'Enhancing Freshman students' Writing Skills with a Mind Mapping software'. Paper presented at the 5th International Scientific Conference, eLearning and Software for Education, Bucharest, April 2009.

Career Center Maine Department of Labor (2001). Today's Work Competencies in Maine

Haylock, Derek. (1997). Recognising Mathematical Creativity in School children. ZDM 29 (3).

Hong, J. C, Mei Y. C.,dan Ming Y. H. (2012). Vitalizing creative learning in science and technologi through an extracurricular club: A perspective based on activity theory. Journal of Thinking Skills and Creativity. 8, $45-55$ 
Hudojo, Herman (2003). Pengembangan Kurikulum dan Pembelajaran Matematika. Malang: Jurusan Pendidikan Matematika, FMIPA Universitas Negeri Malang

Indra, R. (2006).Sukses Sebelum Lulus Kuliah. Bandung: Master Publishing.

Liliawati, W \& Puspita, E. (2010). Efektivitas Pembelajaran Berbasis Masalah Dalam Meningkatkan Keterampilan Berpikir Kreatif Siswa. Prosiding Seminar Nasional Fisika, Bandung.

Martin Prosperity Institute . (2011). Creativity and Prosperity: The Global Creativity Index. University of Toronto. Toronto

Mina, E. (200. Pengaruh Pembelajaran Matematika dengan Pendekatan Open-ended terhadap kemampuan Berpikir Kreatif Matematika Siswa SMA Bandung. Tidak Dipublikasikan. Tesis pada PPs UPI. Bandung.

Munandar, S.C. Utami. (2003). Kreativitas \& Keberbakatan. Strategi Mewujudkan potensi kreatif \& Bakat. Jakarta: PT Gramedia Pustaka Utama

Nugroho, J. (2011). Pemanfaatan media audio visual untuk meningkatkan pembelajaran IPA pada siswa kelas V SDN Kemiriswu 2 Pasuruan. Diakses dari http: /library.um.ac.id/ ptk index.php? $\bmod =$ detdet\&id $=52548$

Osborn, A. (1953). Applied Imagination. Scribner's: New York USA
Pehkonen, Erkki (1997). The State-of-Art in Mathematical Creativity. ZDM Volum 29 (3). Electronic Edition ISSN 1615-679X.

Pepkins, Karen L., (2004). Creative Problem Solving in Math. Diakses dari www.uh.edu /2017.07.15.

Sugiarto. Iwan. (2004) Mengoptimalkan Daya Kerja Otak Dengan Berfikir Holistik dan Kreatif. Jakarta: Gramedia Pustaka Utama.

Sugiyono. (2010). Metode Penelitian Pendidikan Pendekatan Kuantitatif, kualitatif, dan R\&D. Bandung: Alfabeta

Sugiyono (2013). Metode Penelitian Pendidikan Pendekatan Kuantitatif, Kualitatif dan $R \& D$ (Bandung: Alfabeta)

Thiagarajan. (1974). Instructional Development for Training Teachers of Exceptional Chlidren. Indiana:Indiana University Bloomington.

Trianto. (2007). Model-Model Pembelajaran Inovatif Berorientasi Kontruktivistik. Jakarta : Prestasi Pustaka.

Victor, Rene and Valqui Vidal. (2006). Creativity for Designers. Paper Technical University of Denmark.

Wahyudin. (1999). Kemampuan Guru Matematika, Calon Guru Matematika, dan Siswa dalam Mata Pelajaran Matematika. Tidak Dipublikasikan. Disertasi PPs IKIP Bandung. 